\title{
Evaluation of results from use of monitoring Turnip moth (Agrotis segetum Den. et Schiff.) in sugar beet plantation in 2009-2012
}

\author{
Ocena wykorzystania wyników monitoringu rolnicy zbożówki \\ (Agrotis segetum Den. et Schiff.) na plantacjach buraka cukrowego \\ w latach 2009-2012
}

\author{
Magdalena Jakubowska ${ }^{1}$, Jan Bocianowski ${ }^{2}$
}

\begin{abstract}
Summary
The aim of study was an attempt undertaken with Sugar Pfeifer \& Langen Poland Industry to develop ad06sory system for commodity ser06ces and sugar beet growers, regarding a decision on the need of chemical control against cutworm. As a result of carried out observations the date of first moth flights, and the total number of the pests on the plantations were determined. Chemical treatments were applied based on the pest warning system, and phenological criteria such as the sum of heat and effective temperatures for the cutworm development. In the study (2009-2012) the chemical control was set on the basis of signaling between 29th and 41th day from the date of mass flight of moths. The date of chemical treatments was determined with the aid of phenological criteria, such as sum of heat in the range from 497.8 to $661.9^{\circ} \mathrm{C}$ and the sum of effective temperature from 130.6 to $255.8^{\circ} \mathrm{C}$.
\end{abstract}

Key words: monitoring, cutworms, integrated pest management, sums of effective temperature, decision support systems

\section{Streszczenie}

Celem badań przeprowadzonych wspólnie z Cukrownią Pfeifer \& Langen Polska była próba połączenia i wzbogacenia systemów doradczych w podjęciu decyzji o zastosowaniu zabiegu insektycydowego do zwalczania rolnic. W wyniku obserwacji ustalono termin początku wylotów oraz całkowitą liczebność szkodnika na plantacjach. Porównano również przydatność prowadzonego monitoringu odłowów rolnic z systematyczną kontrolą plantacji, od momentu stwierdzenia masowego lotu motyli rolnic. Celem kontroli było zaobserwowanie: początku składania jaj, początku wylęgu pierwszych gąsienic, osiągnięcie przez gąsienice wielkości 10-12 mm oraz ustalenie prognozowanego terminu zabiegu chemicznego zwalczania rolnic. Termin zwalczania szkodnika oparto na podstawie kontroli lotu motyli oraz na wyznaczeniu wartości sumy ciepła i sumy temperatur efektywnych, które wysoce istotnie wpływały na długość rozwoju rolnic do osiągnięcia przez gąsienice stadium $L_{2}$. W latach badań (2009-2012) zabiegi insektycydowe przeciwko rolnicom według sygnalizacji wyznaczono między 29. a 40. dniem od daty wskazującej na początek masowego lotu motyli rolnic. Zabiegi metodą fenologiczną wyznaczono uzyskując sumy ciepła w przedziale od 497,8 do $661,9^{\circ} \mathrm{C}$ oraz sumy temperatur efektywnych od 130,6 do $255,8^{\circ} \mathrm{C}$.

Słowa kluczowe: monitoring, rolnice, integrowana ochrona roślin, sumy temperatur efektywnych, systemy wspomagania decyzji

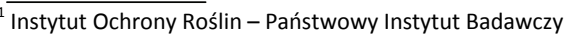

Zakład Metod Prognozowania Agrofagów i Ekonomiki Ochrony Roślin

Władysława Węgorka 20, 60-318 Poznań

M.Jakubowska@iorpib.poznan.pl

${ }^{2}$ Uniwersytet Przyrodniczy w Poznaniu

Katedra Metod Matematycznych i Statystycznych

Wojska Polskiego 28, 60-637 Poznań
} 


\section{Wstęp / Introduction}

W ochronie roślin rolniczych sygnalizacja zagrożeń upraw ze strony szkodników jest dotychczas stosowana w niewielkim zakresie i dotyczy tylko kilku gatunków fitofagów (Walczak i wsp. 2010). Przy wyznaczeniu optymalnego terminu zwalczania agrofagów należy przede wszystkim kierować się prawidłowo prowadzonym monitoringiem szkodnika (Walczak 1999). Polega on na systematycznych obserwacjach i stwierdzeniu w jakim nasileniu występuje lub $\mathrm{w}$ jakim stadium rozwojowym znajduje się szkodnik oraz jaka jest jego liczebność, a w momencie przekroczenia progu ekonomicznej szkodliwości podjęcie decyzji o wykonaniu zabiegu pestycydem (Matyjaszczyk i wsp. 2010; Walczak i wsp. 2010). Badania dotyczące praktycznego wykorzystania oceny metod i technik stosowanych $\mathrm{w}$ monitoringu rolnicy zbożówki podjęto $\mathrm{W}$ związku $\mathrm{z}$ napływającymi informacjami dotyczącymi liczniejszego występowania rolnic w różnych uprawach (Jakubowska i Walczak 2007, 2008, 2009). Poszukiwanie nowych rozwiązań w monitoringu, w aspekcie integrowanej ochrony roślin, w zwalczaniu szkodników glebowych, a w szczególności rolnic, jest tematem aktualnym. Wyznaczenie optymalnego terminu zabiegu za pośrednictwem systematycznych lustracji pól jest ważnym elementem ograniczenia szkodliwości rolnic w stosunku do roślin uprawnych przy jednoczesnym eliminowaniu nadmiernego, niepotrzebnego zużycia środków ochrony roślin, a także ze względów ekologicznych (Garnis i Dąbrowski 2008).

W Polsce, spośród wielu gatunków rolnic, na buraku cukrowym corocznie, występują dwa gatunki: rolnica zbożówka (Agrotis segetum Den. et Schiff.) i rolnica czopówka (A. exclamationis L.) (Jakubowska i Walczak 2009). Owady te są gospodarczo ważnymi szkodnikami glebowymi, powodującymi znaczne szkody na wielu roślinach uprawnych, między innymi, na plantacjach roślin okopowych, warzywnych, zbożowych, ozdobnych w szkółkach (Lipa 1977; Małachowska 1987). Stadium szkodliwym są gąsienice, których zwalczanie, ze względu na ich ukryty tryb życia, jest bardzo trudne. Skuteczne ograniczenie ich szkodliwości uzależnione jest w dużym stopniu od trafnego określenia terminu chemicznego zwalczania. $\mathrm{Z}$ tego powodu, także w przypadku innych szkodników, realizowane są badania zmierzające do poszukiwania zależności pomiędzy tempem ich rozwoju a temperaturą i wilgotnością powietrza dla wspomagania wyznaczania optymalnego terminu zwalczania (Walczak 2003). O szkodliwości rolnic decyduje przede wszystkim ich liczebność, na którą ogromny wpływ mają warunki pogodowe oraz rozciagnięty w czasie, okres wylęgu i rozwoju żarłocznych gąsienic. Szczególnie sprzyjające są mroźne zimy, ciepłe i suche wiosny oraz okres letni, a także suche jesienie (Walczak i Jakubowska 2001; Bereś 2011).

Celem badań, przeprowadzonych wraz z cukrownią Pfeifer \& Langen Polska, była ocena wykorzystania wyników monitoringu rolnicy zbożówki w podjęciu decyzji o zastosowaniu zabiegu insektycydowego do zwalczania rolnic $\mathrm{z}$ uwzględnieniem zasad integrowanej ochrony roślin.

\section{Materiały i metody / Materials and methods}

Badania monitoringowe prowadzone były w latach 2009-2012 przez Zakład Metod Prognozowania Agrofagów i Ekonomiki Ochrony Roślin Instytutu Ochrony Roślin - Państwowego Instytutu Badawczego (IOR - PIB) i firmę Pfeifer \& Langen Polska S.A., na corocznie 13 wybranych plantacjach buraka cukrowego w województwie wielkopolskim i dolnośląskim. Wielkość plantacji, na której prowadzony był monitoring rolnic, wynosiła od 3 do 5 ha. W sumie przez cały okres badawczy monitoring rolnic prowadzono w 21 miejscowościach (rys. 1). Obserwacje dotyczące odłowów imagines szkodnika prowadzono 1-2 razy w tygodniu, w okresie od początku maja do końca lipca. Dorosłe motyle rolnic odławiano za pomocą pułapek świetlnych (samołówki), rozmieszczonych po jednej sztuce na każdej plantacji buraka cukrowego (Jakubowska 2009; Jakubowska i Ławiński 2011; Jakubowska i wsp. 2012). Zebrany materiał biologiczny zidentyfikowano do gatunku oraz poddano analizie ilościowej (Fibiger i Hacker 1991; Nowacki 1996). Podczas odłowów motyli monitorowano przez cały sezon, od maja do końca września, temperaturę oraz wilgotność względną powietrza za pomocą polowych stacji meteorologicznych. Zebrane dane meteorologiczne pochodziły ze stacji polowych należących do Stacji Doświadczalnictwa Polowego: IOR - PIB (Winna Góra) oraz do Centralnego Ośrodka Badania Odmian Roślin Uprawnych (COBORU) (Turew, Szelejewo, Leszno, Kościelna Wieś) i GlaxoSmithKline (GSK - Poznań).

W wyniku obserwacji, analogicznie jak w latach poprzednich, ustalono termin początku wylotów motyli oraz całkowitą liczebność szkodnika na plantacjach. Porównano również przydatność prowadzonego monitoringu odłowów rolnic $\mathrm{z}$ systematyczną kontrolą plantacji od momentu stwierdzenia masowego lotu motyli. Kontrola posłużyła do zaobserwowania początku składania jaj, wylęgu pierwszych gąsienic, osiągnięcia przez gąsienice wielkości 10-12 mm oraz ustalenia proponowanego terminu zabiegu chemicznego. Termin zwalczania szkodnika ustalono na podstawie kontroli lotu motyli według Zacha (1966) oraz na jednoczesnym wyznaczeniu wartości sum ciepła i sum temperatur efektywnych, które wysoce istotnie wpływały na długość rozwoju rolnic do osiągnięcia przez nie odpowiedniego stadium rozwojowego - $\mathrm{L}_{2}$ (Walczak 2003; Jakubowska 2009). Termin zabiegu według kryterium fenologicznego wyznaczono, dla każdej analizowanej miejscowości, sumując średnie dobowe temperatury powietrza dla minimum 30 dni, od dnia określenia daty początkowej masowego nalotu motyli.

Uzyskane wyniki liczebności gatunku rolnicy zbożówki z przeprowadzonego monitoringu opracowano statystycznie. Jednoczynnikowa analiza wariancji (ANOVA) przy poziomie istotności $\alpha=0,05$ została zastosowana do weryfikacji hipotezy zerowej o braku wpływu lat na liczebność rolnicy zbożówki. Podobnie, jednoczynnikową analizę wariancji zastosowano do weryfikacji hipotezy o wpływie miejscowości na liczebność obserwowanej rolnicy zbożówki. Obliczono najmniejszą istotną różnicę 


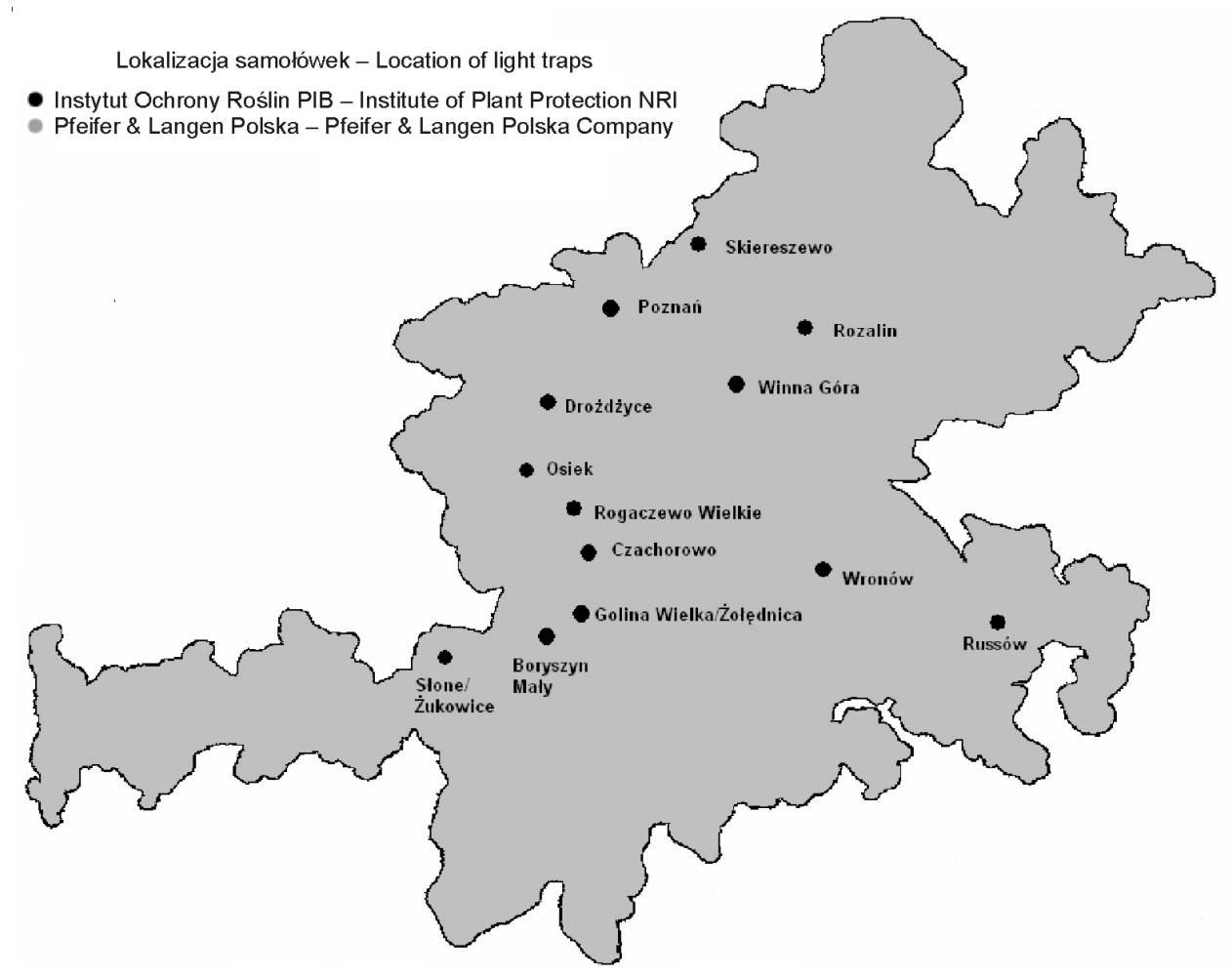

Rys. 1. Mapka rozmieszczenia pułapek świetlnych na monitorowanych plantacjach w roku 2012

Fig. 1. Map of light traps distribution for monitoring plantations in 2012

(NIR 0,05) dla liczebności rolnicy zbożówki i na jej podstawie wyznaczono grupy jednorodne. Model regresji prostej zastosowano do analizy wpływu sumy ciepła i sumy temperatur efektywnych na liczebność rolnicy zbożówki.

\section{Wyniki i dyskusja / Results and discussion}

Podobnie, jak w latach poprzednich dla potrzeb prognozowania krótkoterminowego, w okresie czteroletnich badań w warunkach kontrolowanych i polowych, wyznaczono wartości sum ciepła $-501,1^{\circ} \mathrm{C}$ i sum temperatur efektywnych $-230,0^{\circ} \mathrm{C}$ dla badanego okresu rozwojowego rolnic.

$\mathrm{Na}$ podstawie przeprowadzonego monitoringu przy użyciu pułapek świetlnych wykazano obecność czterech gatunków rolnic $\mathrm{W}$ zasiewach buraka cukrowego. Najliczniejszymi były A. segetum i A. exclamationis. $\mathrm{Na}$ liczebność poszczególnych gatunków motyli z podrodziny Noctuinae istotny wpływ mogły mieć zasiewy innych roślin żywicielskich otaczające monitorowane plantacje z burakiem cukrowym. Potwierdzają to również inni autorzy zajmujący się problematyką rolnic (Walczak i Jakubowska 2001; Garnis i Dąbrowski 2008; Bereś 2011; Jakubowska i Ławiński 2011). W badaniach własnych stwierdzono, że liczniej odławiano rolnicę zbożówkę (A. segetum) niż rolnicę czopówkę (A. exclamationis). $\mathrm{W}$ badaniach nad dynamiką występowania motyli rolnic prowadzonych przy pomocy pułapki świetlnej stwierdzono, że na poziom efektywności odłowów w dużej mierze miał wpływ przebieg warunków pogodowych.
W roku 2012 pierwsze motyle rolnicy zbożówki, odławiano we Wronowie 7 maja, w Boryszynie Małym 10 maja, w Poznaniu 13 maja oraz w Osieku 15 maja. Najpóźniej wylot motyli obserwowano w Skiereszewie 28 maja (tab. 1). Masowe składanie jaj obserwowano w połowie maja i trwało ono do końca czerwca. Początkowe stadium gąsienic $\mathrm{L}_{1}$ obserwowano na plantacjach w pierwszej dekadzie czerwca. Pod koniec miesiąca, ze względu na sprzyjające dla rozwoju szkodnika warunki meteorologiczne na monitorowanych plantacjach odnotowano różne stadia rozwojowe gąsienic rolnic od $\mathrm{L}_{1}$ do $\mathrm{L}_{4}$. Średni prognozowany termin chemicznego zwalczania rolnic w roku 2012 dla monitorowanych miejscowości przypadł na 34 dzień (29-50 dzień).

W roku 2012 w oparciu o sygnalizację, wyznaczono termin zabiegu w dniach: 15, 22, 25 i 29 czerwca, tj. pomiędzy 29. a 39. dniem od daty początkowej, wskazującej na masowy lot motyli rolnic. Średnia suma ciepła, jaką odnotowano dla miejscowości: Januszewo, Boryszyn Mały, Staniew i Poznań wyniosła $392,67^{\circ} \mathrm{C}$ (zabieg insektycydowy wykonany 15 czerwca). W miejscowościach: Czachorowo, Żukowice, Drożdżyce, Winna Góra oraz Russów zabieg insektycydowy wykonano 22 czerwca. Średnia suma ciepła jaką odnotowano wyniosła $478,84^{\circ} \mathrm{C}$. W pozostałych miejscowościach zabieg zastosowano 25 czerwca, gdy suma ciepła wyniosła $471,03^{\circ} \mathrm{C}$. Tylko w miejscowości Dębnica ze względów technicznych zabieg insektycydowy został wykonany pod koniec czerwca, gdy suma ciepła przekroczyła wartość sumy zakładanej w badaniach $\left(501,1^{\circ} \mathrm{C}\right)$ i wyniosła $602,1^{\circ} \mathrm{C}$ (tab. 2, rys. 2). Średnia temperatura powietrza dla tego 
Tabela 1. Monitoring odłowu motyli rolnic przeprowadzony w roku 2012

Table 1. Monitoring catch moths of cutworms carried out in 2012

\begin{tabular}{l|l|c|c|c}
\hline \multicolumn{1}{c|}{ Rok - Year } & \multicolumn{3}{|c}{2012} \\
\multicolumn{1}{c|}{ Miejscowości } & $\begin{array}{c}\text { gmina } \\
\text { district }\end{array}$ & $\begin{array}{c}\text { początek masowego } \\
\text { nalotu motyli rolnic } \\
\text { start of mass moths' } \\
\text { flight }\end{array}$ & $\begin{array}{c}\text { liczba odłowionych } \\
\text { imagines } \\
\text { number of captured adults } \\
\text { A. segetum Schiff. }\end{array}$ & $\begin{array}{c}\text { prognozowany termin zwalczania } \\
\text { predicted date of chemical treatment }\end{array}$ \\
\hline Wronów & Krotoszyn & 07.05 & 8 & $06.06-11.06$ \\
Boryszyn Mały & Góra Śląska & 10.05 & 19 & $09.06-13.06$ \\
Poznań & Poznań & 13.05 & 7 & $12.06-17.06$ \\
Osiek & Kościan & 15.05 & 10 & $14.06-19.06$ \\
Winna Góra & Środa Wlkp. & 17.05 & 12 & $16.06-21.06$ \\
Czachorowo & Gostyń & 19.05 & 3 & $18.06-23.06$ \\
Żukowice/Słone & Głogów & 20.05 & 15 & $19.06-22.06$ \\
Russów & Żelazków & 21.05 & 14 & $20.06-25.06$ \\
Drożdżyce & Stęszew & 22.05 & $11.06-26.06$ \\
Rogaczewo Wielkie & Krzywiń & 22.05 & 0 & $21.06-26.06$ \\
Rozalin & Słupia & 23.05 & 5 & $22.06-27.06$ \\
Żołędnica & Miejska Górka & 24.05 & 5 & $23.06-28.06$ \\
Skiereszewo & Gniezno & 28.05 & $27.06-01.07$ \\
\hline
\end{tabular}

Tabela 2. Terminy zabiegów insektycydowych przeprowadzonych w latach 2009-2012

Table 2. Date of chemical treatments carried out in 2009-2012

\begin{tabular}{|c|c|c|c|c|c|c|c|c|c|}
\hline \multirow[b]{2}{*}{$\begin{array}{l}\text { Rok } \\
\text { Year }\end{array}$} & \multirow[b]{2}{*}{$\begin{array}{l}\text { Miejscowość } \\
\text { Localities }\end{array}$} & \multirow[b]{2}{*}{$\begin{array}{c}\text { Gmina } \\
\text { Community }\end{array}$} & \multicolumn{3}{|c|}{$\begin{array}{l}\text { Kryterium sygnalizacji } \\
\text { The criterion for signalling }\end{array}$} & \multicolumn{4}{|c|}{$\begin{array}{l}\text { Kryterium fenologiczne } \\
\text { The phenological criteria }\end{array}$} \\
\hline & & & $\begin{array}{c}\text { data zabiegu } \\
\text { chemicznego } \\
\text { date } \\
\text { of chemical } \\
\text { treatments }\end{array} \mid$ & $\begin{array}{l}\text { suma } \\
\text { ciepła } \\
\text { sum } \\
\text { of heat } \\
{\left[{ }^{\circ} \mathrm{C}\right]}\end{array}$ & $\begin{array}{c}\text { stadium } \\
\text { rozwojowe } \\
\text { developmental } \\
\text { stage }\end{array}$ & $\begin{array}{c}\text { data zabiegu } \\
\text { chemicznego } \\
\text { date } \\
\text { of chemical } \\
\text { treatments }\end{array}$ & $\begin{array}{l}\text { suma } \\
\text { ciepła } \\
\text { sum } \\
\text { of heat } \\
{\left[{ }^{\circ} \mathrm{C}\right]}\end{array}$ & \begin{tabular}{|c|} 
sumy \\
temperatur \\
efektywnych \\
sum \\
of effective \\
temperatures \\
{$\left[{ }^{\circ} \mathrm{C}\right]$} \\
\end{tabular} & \begin{tabular}{|c} 
stadium \\
rozwojowe \\
developmental \\
stage \\
\end{tabular} \\
\hline 1 & 2 & 3 & 4 & 5 & 6 & 7 & 8 & 9 & 10 \\
\hline \multirow{5}{*}{2009} & Żukowice & Głogów & 20.06 & 543,0 & $\mathrm{~L}_{2}$ & 18.06 & 511,4 & 123,5 & $\mathrm{~L}_{2}-\mathrm{L}_{3}$ \\
\hline & Żołędnica & $\begin{array}{l}\text { Miejska } \\
\text { Górka }\end{array}$ & 22.06 & 522,0 & $\mathrm{~L}_{2}$ & 19.06 & 507,4 & 126,3 & $\mathrm{~L}_{2}-\mathrm{L}_{3}$ \\
\hline & Dębnica & Kłecko & 22.06 & 512,4 & $\mathrm{~L}_{2}$ & 19.06 & 484,9 & 133,4 & $\mathrm{~L}_{2}-\mathrm{L}_{3}$ \\
\hline & Poznań & Poznań & 22.06 & 527,5 & $\mathrm{~L}_{2}$ & 20.06 & 501,3 & 143,5 & $\mathrm{~L}_{2}-\mathrm{L}_{3}$ \\
\hline & Russów & Żelazków & 20.06 & 538,1 & $\mathrm{~L}_{2}$ & 18.06 & 507,3 & 120,2 & $\mathrm{~L}_{2}-\mathrm{L}_{3}$ \\
\hline \multirow{10}{*}{2010} & Januszewo & Kościan & 28.06 & 543,82 & $\mathrm{~L}_{2}-\mathrm{L}_{3}$ & 28.06 & 543,82 & 166,62 & $\mathrm{~L}_{2}-\mathrm{L}_{3}$ \\
\hline & Żukowice & Głogów & 28.06 & 470,7 & $\mathrm{~L}_{2}$ & 26.06 & 454,4 & 149,2 & $\mathrm{~L}_{2}-\mathrm{L}_{3}$ \\
\hline & Boryszyn Mały & $\begin{array}{l}\text { Góra } \\
\text { Śląska }\end{array}$ & 28.06 & 444,3 & $\mathrm{~L}_{2}$ & 26.06 & 428,0 & 144,6 & $\mathrm{~L}_{2}-\mathrm{L}_{3}$ \\
\hline & Choryń & Kościan & 1.07 & 539,1 & $\mathrm{~L}_{2}-\mathrm{L}_{3}$ & 28.06 & 502,1 & 128,62 & $\mathrm{~L}_{2}$ \\
\hline & Staniew & Koźmin & 1.07 & 547,7 & $\mathrm{~L}_{2}-\mathrm{L}_{3}$ & 28.06 & 502,1 & 175,1 & $\mathrm{~L}_{2}$ \\
\hline & Poznań & Poznań & 1.07 & 522,8 & $\mathrm{~L}_{2}-\mathrm{L}_{3}$ & 29.06 & 504,9 & 168,2 & $\mathrm{~L}_{2}$ \\
\hline & Drożdżyce & Stęszew & 1.07 & 504,9 & $\mathrm{~L}_{2}$ & 29.06 & 481,9 & 156,1 & $\mathrm{~L}_{2}-\mathrm{L}_{3}$ \\
\hline & Rozalin & Słupia & 5.07 & 604,1 & $\mathrm{~L}_{2}-\mathrm{L}_{3}$ & 30.06 & 503,9 & 176,9 & $\mathrm{~L}_{2}$ \\
\hline & Winna Góra & $\begin{array}{l}\text { Środa } \\
\text { Wlkp. }\end{array}$ & 4.07 & 576,2 & $\mathrm{~L}_{2}-\mathrm{L}_{3}$ & 29.06 & 470,4 & 165,2 & $\mathrm{~L}_{2}$ \\
\hline & Russów & Żelazków & 1.07 & 615,3 & $\mathrm{~L}_{2}-\mathrm{L}_{3}$ & 28.06 & 565,4 & 183,9 & $\mathrm{~L}_{2}-\mathrm{L}_{3}$ \\
\hline
\end{tabular}




\begin{tabular}{|c|c|c|c|c|c|c|c|c|c|}
\hline 1 & 2 & 3 & 4 & 5 & 6 & 7 & 8 & 9 & 10 \\
\hline \multirow{13}{*}{2011} & Januszewo & Kościan & 17.06 & 488,7 & $\mathrm{~L}_{2}$ & 15.06 & 443,92 & 182,32 & $\mathrm{~L}_{2}$ \\
\hline & Czachorowo & Gostyń & 11.06 & 537,0 & $\mathrm{~L}_{2}$ & 9.06 & 502,0 & 197,1 & $\mathrm{~L}_{2}$ \\
\hline & Żukowice/Słone & Głogów & 15.06 & 632,5 & $\mathrm{~L}_{2}$ & 10.06 & 507,9 & 191,6 & $\mathrm{~L}_{2}$ \\
\hline & Boryszyn Mały & $\begin{array}{l}\text { Góra } \\
\text { Śląska }\end{array}$ & 17.06 & 502,4 & $\mathrm{~L}_{2}$ & 15.06 & 462,2 & 189,7 & $\mathrm{~L}_{2}$ \\
\hline & Choryń & Kościan & $4.06 \mathrm{I}$ & 696,4 & $\mathrm{~L}_{3}$ & 20.06 & 519,2 & 214,0 & $\mathrm{~L}_{2}-\mathrm{L}_{3}$ \\
\hline & Staniew/Wronów & Koźmin & 25.06 & 427,25 & $\mathrm{~L}_{2}-\mathrm{L}_{3}$ & 29.06 & 504,2 & 209,9 & $\mathrm{~L}_{2}-\mathrm{L}_{3}$ \\
\hline & Żołędnica & $\begin{array}{l}\text { Miejska } \\
\text { Górka }\end{array}$ & 22.06 & 551,6 & $\mathrm{~L}_{2}-\mathrm{L}_{3}$ & 17.06 & 500,0 & 205,7 & $\mathrm{~L}_{2}-\mathrm{L}_{3}$ \\
\hline & Dębnica/Skiereszewo & Kłecko & 30.06 & 561,3 & $\mathrm{~L}_{2}-\mathrm{L}_{3}$ & 23.06 & 514,7 & 242,2 & $\mathrm{~L}_{2}-\mathrm{L}_{3}$ \\
\hline & Poznań & Poznań & 20.06 & 687,3 & $\mathrm{~L}_{3}-\mathrm{L} 4$ & 10.06 & 497,8 & 225,3 & $\mathrm{~L}_{2}-\mathrm{L}_{3}$ \\
\hline & Drożdżyce & Stęszew & 22.06 & 652,8 & $\mathrm{~L}_{2}-\mathrm{L}_{3}$ & 17.06 & 565,7 & 260,5 & $\mathrm{~L}_{3}$ \\
\hline & Rozalin & Słupia & 15.06 & 593,0 & $\mathrm{~L}_{2}-\mathrm{L}_{3}$ & 10.06 & 503,8 & 198,6 & $\mathrm{~L}_{2}-\mathrm{L}_{3}$ \\
\hline & Winna Góra & $\begin{array}{l}\text { Środa } \\
\text { Wlkp. }\end{array}$ & 20.06 & 606,0 & $\mathrm{~L}_{3}$ & 15.06 & 513,7 & 219,4 & $\mathrm{~L}_{2}-\mathrm{L}_{3}$ \\
\hline & Russów & Żelazków & 20.06 & 574,0 & $\mathrm{~L}_{2}-\mathrm{L}_{3}$ & 16.06 & 505,1 & 211,2 & $\mathrm{~L}_{2}-\mathrm{L}_{3}$ \\
\hline \multirow{10}{*}{2012} & Januszewo/Osiek & Kościan & 15.06 & 482,6 & $\mathrm{~L}_{2}$ & 16.06 & 502,9 & 140,6 & $\mathrm{~L}_{2}$ \\
\hline & Czachorowo & Gostyń & 22.06 & 579,0 & $\mathrm{~L}_{2}-\mathrm{L}_{3}$ & 18.06 & 505,0 & 167,2 & $\mathrm{~L}_{2}$ \\
\hline & Rogaczewo & Kościan & 25.06 & 431,5 & $\mathrm{~L}_{2}-\mathrm{L}_{3}$ & 27.06 & 465,2 & 149,9 & $\mathrm{~L}_{2}-\mathrm{L}_{3}$ \\
\hline & Staniew/Wronów & Koźmin & 15.06 & 300,7 & $\mathrm{~L}_{2}$ & 26.06 & 507,1 & 182,0 & $\mathrm{~L}_{3}$ \\
\hline & Dębnica/Skiereszewo & Kłecko & 29.06 & 564,9 & $\mathrm{~L}_{3}$ & 26.06 & 507,1 & 182,0 & $\mathrm{~L}_{2}-\mathrm{L}_{3}$ \\
\hline & Poznań & Poznań & 15.06 & 547,6 & $\mathrm{~L}_{3}-\mathrm{L}_{4}$ & 13.06 & 516,4 & 175,8 & $\mathrm{~L}_{2}-\mathrm{L}_{3}$ \\
\hline & Drożdżyce & Stęszew & 22.06 & 556,7 & $\mathrm{~L}_{2}-\mathrm{L}_{3}$ & 22.06 & 556,7 & 209,8 & $\mathrm{~L}_{2}-\mathrm{L}_{3}$ \\
\hline & Rozalin & Słupia & 25.06 & 556,49 & $\mathrm{~L}_{2}-\mathrm{L}_{3}$ & 22.06 & 500,4 & 164,7 & $\mathrm{~L}_{2}-\mathrm{L}_{3}$ \\
\hline & Winna Góra & $\begin{array}{l}\text { Środa } \\
\text { Wlkp. }\end{array}$ & 22.06 & 502,8 & $\mathrm{~L}_{3}$ & 22.06 & 502,8 & 169,1 & $\mathrm{~L}_{2}-\mathrm{L}_{3}$ \\
\hline & Russów & Żelazków & 22.06 & 381,7 & $\mathrm{~L}_{2}$ & 26.06 & 448,2 & 143,8 & $\mathrm{~L}_{2}-\mathrm{L}_{3}$ \\
\hline
\end{tabular}

okresu wynosząca $19,1^{\circ} \mathrm{C}$ w porównaniu z latami poprzednimi była temperaturą sprzyjającą dla rozwoju szkodników. Obserwowane w tym czasie gąsienice osiągnęły stadium $\mathrm{L}_{2} \mathrm{i} \mathrm{L}_{3}$, tj. miały od 12 do $17 \mathrm{~mm}$ długości, a w Poznaniu przekroczyły nawet $24 \mathrm{~mm}$ (stadium $\mathrm{L}_{4}$ ). Analiza liczebności gąsienic wykonana 19 czerwca wykazała średnio 2,6 osobnika na $1 \mathrm{~m}^{2}$. Próg szkodliwości nie został osiągnięty. Podsumowując, można stwierdzić, że na podstawie wielkości obserwowanych gąsienic zabieg chemiczny według sygnalizacji został wyznaczony z niewielkim opóźnieniem.

Zabieg wyznaczony drugim sposobem, z wykorzystaniem sum ciepła i sum temperatur efektywnych, dla całego badanego okresu rozwojowego rolnic wyznaczono na dzień 13 czerwca dla miejscowości Poznań i Januszewo. Wartości sum ciepła osiągnęły odpowiednio: 516,4 i $502,9^{\circ} \mathrm{C}$, a sumy temperatur efektywnych: 175,8 i $140,6^{\circ} \mathrm{C}$. Kolejnym terminem, jaki wyznaczono dla pozostałych miejscowości był 18 czerwca. Uzyskano sumy ciepła i sumy temperatur efektywnych wynoszące od 303,4 i $87,1^{\circ} \mathrm{C}$, dla miejscowości Żukowice do $505,0^{\circ} \mathrm{C}$ i $167,2^{\circ} \mathrm{C}$ dla miejscowości Czachorowo (tab. 2). Analiza liczebności rolnic wykonana 20 czerwca wykazała średnio 1,7 osobnika na $1 \mathrm{~m}^{2}$. Próg szkodliwości nie został osiągnięty. Wyznaczony zabieg przypadł średnio na 34 dzień od daty wskazanej jako początek masowego lotu motyli. Podobnie, jak dla potrzeb sygnalizacji, obserwowane $\mathrm{w}$ tym czasie na polu gassienice rolnic osiagały różną wielkość od 0,6 do $19 \mathrm{~mm}$ (stadium $\mathrm{L}_{1}-\mathrm{L}_{3}$ ).

Podsumowując, można stwierdzić, że zabieg chemiczny według kryterium fenologicznego i sygnalizacyjnego w roku 2012 został wyznaczony z niewielkim opóźnieniem, gdyż dla wielu monitorowanych plantacji zostały przekroczone wartości sum ciepła. Analizy gleby wykazały, iż obserwowane gąsienice rolnic miały wielkość od 9 do $17 \mathrm{~mm}$, co odpowiadałoby stadium $\mathrm{L}_{2}-\mathrm{L}_{3}$. Ponadto, zabiegi chemiczne przeprowadzone $\mathrm{W}$ wyznaczonych terminach przeciwko tym agrofagom na podstawie kontroli lotu i w oparciu o lustracje pól wpłynęły na zahamowanie rozwoju szkodnika na plantacjach buraka cukrowego.

Przeprowadzona analiza wariancji dla liczebności odłowionych samców rolnicy zbożówki (A. segetum) 

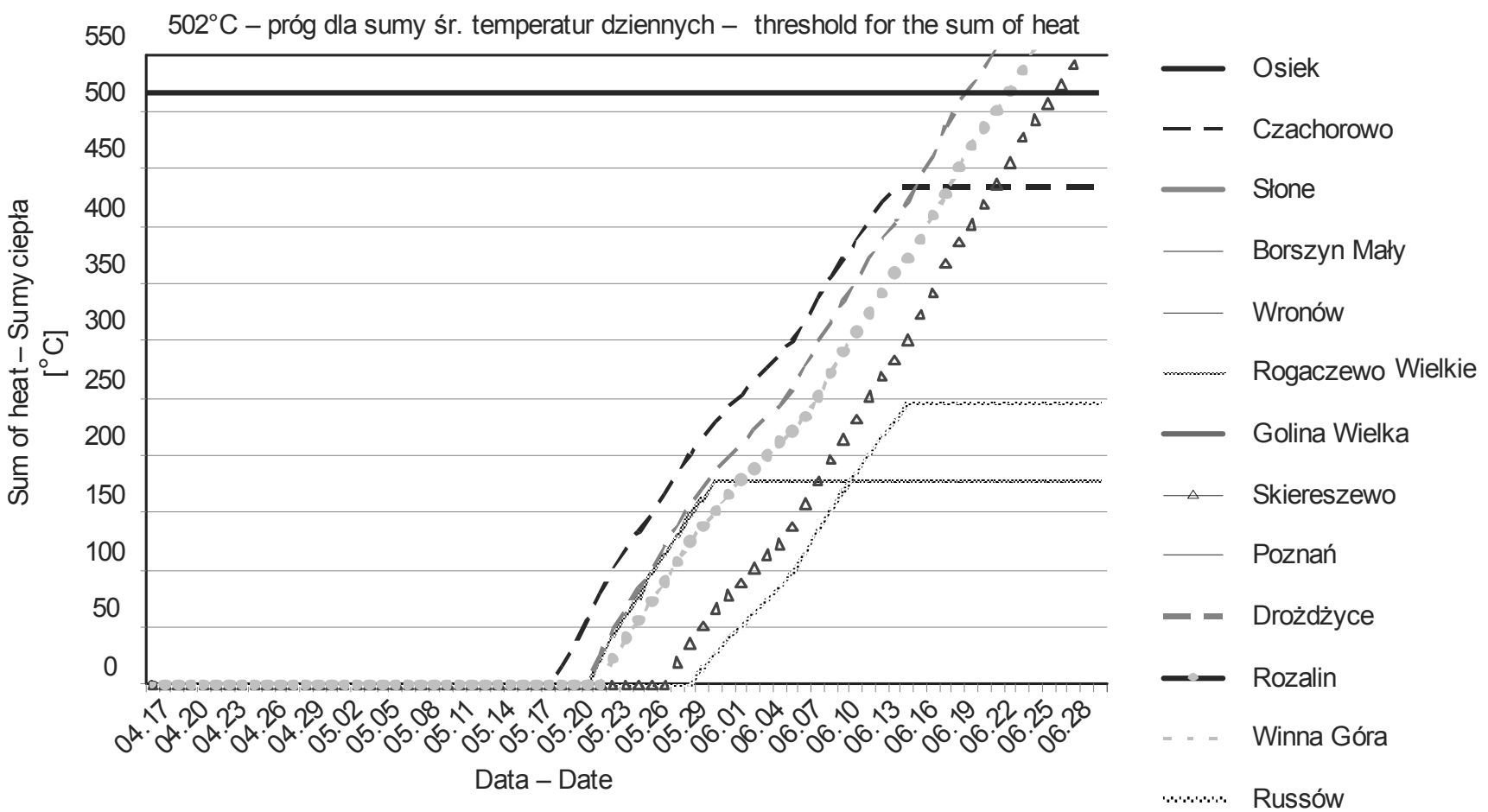

Sumy ciepła obliczone dla 13 miejscowości

The sums of heat calculated for 13 localities

Rys. 2. Terminy zabiegów insektycydowych wyznaczonych na podstawie sum ciepła na terenie 13 miejscowości w roku 2012

Fig. 2. Dates of chemical treatments appointed on the basis sums of heat in 13 localities in 2012

Tabela 3. Wartości średnie i odchylenia standardowe liczebności występowania rolnicy zbożówki w poszczególnych miejscowościach w latach 2009-2012

Table 3. The mean values and standard de06ations of the number of occurrence of Turnip moth in particular localities in 2009-2012

\begin{tabular}{|c|c|c|c|c|c|c|}
\hline \multirow{2}{*}{$\begin{array}{l}\text { Miejscowości } \\
\text { Localities }\end{array}$} & \multicolumn{4}{|c|}{ Lata - Years } & \multirow{2}{*}{$\begin{array}{l}\text { Średnia } \\
\text { Mean }\end{array}$} & \multirow{2}{*}{$\begin{array}{c}\text { Odchylenie } \\
\text { standardowe } \\
\text { Standard dewiation }\end{array}$} \\
\hline & 2009 & 2010 & 2011 & 2012 & & \\
\hline 1 & 2 & 3 & 4 & 5 & 6 & 7 \\
\hline Boryszyn Mały & 8 & 12 & 4 & 19 & $10,75 \mathrm{abcd}$ & 6,397 \\
\hline Choryń & $*$ & 4 & 0 & $*$ & $2 \mathrm{ef}$ & 2,828 \\
\hline Czachorowo & $*$ & 2 & 9 & 3 & 4,667 cdef & 3,786 \\
\hline Dębnica & 10 & 3 & 1 & $*$ & 4,667 cdef & 4,726 \\
\hline Drożdżyce & 0 & 5 & 2 & 11 & 4,5 cdef & 4,796 \\
\hline Gola & 7 & $*$ & $*$ & $*$ & 7 bcdef & - \\
\hline Góreczki & 5 & $*$ & $*$ & $*$ & 5 bcdef & - \\
\hline Januszewo & $*$ & 5 & 21 & $*$ & $13 \mathrm{ab}$ & 11,314 \\
\hline Kopaszewo & 0 & $*$ & $*$ & $*$ & $0 \mathrm{f}$ & - \\
\hline Nacław & 0 & $*$ & $*$ & $*$ & $0 \mathrm{f}$ & - \\
\hline Osiek & $*$ & $*$ & $*$ & 10 & 10 abcde & - \\
\hline Poznań & 3 & 5 & 5 & 7 & 5 bcdef & 1,633 \\
\hline Rogaczewo & $*$ & $*$ & $*$ & 0 & $0 \mathrm{f}$ & - \\
\hline Rozalin & 19 & 17 & 3 & 8 & $11,75 \mathrm{abc}$ & 7,544 \\
\hline Russów & 19 & 8 & 27 & 14 & $17 \mathrm{a}$ & 8,042 \\
\hline Skiereszewo & $*$ & $*$ & $*$ & 5 & 5 bcdef & - \\
\hline Staniew & $*$ & 0 & 0 & $*$ & $0 \mathrm{f}$ & 0 \\
\hline Winna Góra & 4 & 9 & 1 & 12 & 6,5 bcdef & 4,933 \\
\hline Wronów & $*$ & $*$ & $*$ & 8 & 8 bcdef & - \\
\hline Żołędnica & 3 & 0 & 2 & 5 & $2,5 \mathrm{def}$ & 2,082 \\
\hline
\end{tabular}




\begin{tabular}{l|c|c|c|c|c|c}
\hline \multicolumn{1}{c|}{1} & 2 & 3 & 4 & 5 & 6 & 7 \\
\hline Żukowice & 0 & 13 & 12 & 15 & 10 abcde & 6,782 \\
\hline Średnia-Mean & $6 \mathrm{a}$ & $6,385 \mathrm{a}$ & $6,692 \mathrm{a}$ & $9 \mathrm{a}$ & - & - \\
\hline $\begin{array}{l}\text { Odchylenie standardowe } \\
\text { Standard de06ation }\end{array}$ & 6,621 & 5,173 & 8,528 & 5,244 & - & - \\
\hline
\end{tabular}

*brak danych - lack of date

Wartości w kolumnach oznaczone jednakowymi literami nie różnią się istotnie na poziomie $\alpha=0,05$

Means in columns followed by the same letters are not significantly different at according to $\alpha=0.05$

wykazała, że czynnikiem różnicującym nie były lata prowadzenia obserwacji $\left(\mathrm{F}_{3,48}=0,56 ; \mathrm{p}=0,647\right)$. Zaobserwowano natomiast istotne statystycznie różnice pomiędzy miejscowościami, w których prowadzony był monitoring $\left(\mathrm{F}_{20,31}=2,47 ; \mathrm{p}=0,012\right)$ (tab. 3).

Porównując lata 2009-2012 można powiedzieć, że rok 2011 był rokiem sprzyjającym rozwojowi gąsienic rolnic. Okresowe zwiększenie się liczebności rolnic zaobserwowano w roku 2009, na co wskazywał bardzo liczny lot motyli gatunków A. segetum. W roku 2010 ze względu na niekorzystne warunki pogodowe lot motyli rolnic był opóźniony. Maksimum lotów przypadało na lipiec i sierpień. Lata 2011 i 2012 są kolejnymi, gdzie obserwowano okres ukrytego narastania gradacji szkodnika. Naloty motyli monitorowanych gatunków Noctuinae na obserwowanych plantacjach rozpoczynały się przeważnie od trzeciej dekady maja (lata 2009 i 2011) i trwały do pierwszej połowy lipca. Długość lotu motyli zależała głównie od warunków pogodowych. Początek składania jaj przez rolnice w latach badań obserwowano od końca maja do pierwszej połowy czerwca. Ciepła i wilgotna pogoda, z wyjątkiem roku 2010 sprawiła, że początek wylęgów gassienic obserwowano od 5 do 17 czerwca. W roku 2009 według sygnalizacji w 13 miejscowościach wyznaczono zabieg pomiędzy 31. a 38. dniem od daty początkowej. Średnia temperatura dla tego okresu wynosząca $15,8^{\circ} \mathrm{C}$ $\mathrm{W}$ porównaniu $\mathrm{z}$ rokiem poprzednim była temperaturą niesprzyjającą dla rozwoju gąsienic. Zabieg wyznaczono pomiędzy 20 a 22 czerwca (tab. 2). Termin zabiegu wyznaczony drugim sposobem z wykorzystaniem wartości sum temperatur efektywnych i sum ciepła dla całego badanego okresu rozwojowego rolnic wyznaczono na dzień 18 czerwca dla miejscowości Żukowice i Russów (wartości sum ciepła osiągnęły odpowiednio 511,4 i $\left.507,3^{\circ} \mathrm{C}\right)$. Następnie na dzień $19-20$ czerwca dla miejscowości Żołędnica $-507,4^{\circ} \mathrm{C}$, Poznań $-501,3^{\circ} \mathrm{C}$ i Dębnica $-501,1^{\circ} \mathrm{C}$. W pozostałych miejscowościach termin chemicznego zabiegu wyznaczono w dniach 23-25 czerwca. W sezonie wegetacyjnym 2010, na podstawie kontroli lotu motyli wyznaczono termin wykonania zabiegu chemicznego między 29. a 35. dniem, licząc od następnego dnia po określeniu daty początku masowego lotu motyli. Uznano, że średnia temperatura dla okresu 30 dni, wynosząca $16,8^{\circ} \mathrm{C}$ wskazywała w porównaniu z poprzednimi latami, że z powodu ochłodzenia należy dodać zgodnie z założeniami metodycznymi jeszcze 5 dni. Termin zabiegu wyznaczono na 1-5 lipca, a zwalczane gąsienice osiągnęły wówczas stadium $\mathrm{L}_{2}$ (tab. 3). Zabieg w oparciu o kryterium fenologiczne wyznaczono, sumując następnego dnia po określeniu daty początkowej (dla każdej analizowanej miejscowości) średnie dobowe temperatury powietrza dla minimum 29 dni. Uzyskano sumy ciepła wynoszące od $502,1^{\circ} \mathrm{C}$ dla miejscowości Staniew i do $515,5^{\circ} \mathrm{C}$ dla miejscowości Januszewo. Termin zabiegu przypadł na 28-30 czerwca. Wykopane w tym czasie $\mathrm{z}$ gleby gąsienice osiagały stadium $\mathrm{L}_{2}$. Wyniki przeprowadzonej analizy regresji wskazują na istotny statystycznie $(\mathrm{p}<0,001)$ wpływ zarówno sumy ciepła, jak i sumy temperatur efektywnych na liczebność rolnicy zbożówki. Wyniki te korespondują z wcześniejszymi badaniami monitoringowymi rolnic przeprowadzonymi na plantacjach buraków cukrowych (Jakubowska i Ławiński 2011, 2012). Dane literaturowe wskazują, że zarówno temperatura, jak i wilgotność mają zróżnicowany wpływ w poszczególnych okresach rozwojowych szkodników, tzn. inne warunki potrzebne są dla okresu składania jaj, wylęgu gąsienic, czy dalszego ich rozwoju. Podobne spostrzeżenia można znaleźć w pracy Tribela i wsp. (2004), którzy prowadzili hodowlę rolnic w różnych zakresach temperatur i terminach rozwoju gąsienic, w warunkach polowych.

Prognozowanie i kontrolowanie rozwoju populacji rolnic jest bardzo trudne, gdyż brak jest korelacji pomiędzy liczbą odławianych osobników motyli a liczebnością gąsienic na uprawach roślin. $\mathrm{Z}$ tego względu bardzo ważne jest opracowanie sposobów prognozowania i oceny nasilenia występowania badanych Noctuinae. Prace badawcze dotyczące prognozowania krótkoterminowego oparte na tzw. stopniodniach (degree-day), tj. na sumowaniu temperatur od ustalonej umownie daty, dla określenia sumy ciepła, jaka jest potrzebna do osiagnięcia odpowiedniego stadium rozwojowego szkodnika realizowane, sa od lat siedemdziesiątych i osiemdziesiątych w: Stanach Zjednoczonych, Danii, Niemczech, Holandii, a także współcześnie i w Polsce (Allen 1976; Pruess 1983; McMaster i Wilhelm 1997; Bonhomme 2000; Juszczak i wsp. 2008). Uzyskane wyniki są obiecujące i wskazują na możliwość zastosowania na szerszą skalę zwalczania rolnic $\mathrm{z}$ wykorzystaniem sum ciepła i sum temperatur efektywnych po wyznaczeniu krytycznego dnia lotu motyli za pomoca samołówki.

\section{Wnioski / Conclusions}

1. Opracowano metodę prognozy krótkoterminowej dla ustalenia optymalnego terminu zwalczania rolnic na podstawie przeprowadzonej dokładnej lustracji i śledzenia szkodliwych faz rozwojowych owada.

2. Wartości sum ciepła i sum temperatur efektywnych są elementem wspomagającym ustalenie optymalnego 
terminu wykonania zabiegu chemicznego przeciwko szkodnikom. Przy wyznaczeniu terminu chemicznego zwalczania należy uwzględnić również próg ekonomicznej szkodliwości.
3. Najlepsze efekty chemicznego zwalczania rolnic w latach badań uzyskano, gdy szkodnik osiągnął pełne stadium $\mathrm{L}_{2}$ i początek stadium $\mathrm{L}_{3}$. Obserwowane rośliny buraka cukrowego były w fazie BBCH $31-35$.

\section{Literatura / References}

Allen J.C. 1976. A modified sine wale metod for calculating degree days. En06ron. Entomol 5: 388-396.

Bonhomme R. 2000. Bases and limits to using ‘degree-day' units. Eur. J. Agron. 13: 1-10.

Bereś P. 2011. Występowanie oraz szkodliwość rolnic (Agrotinae) dla kukurydzy (Zea mays L.) w południowo-wschodniej Polsce w latach 2004-2010. [Occurrence and harmfulness of cutworms (Agrotinae) on maize (Zea mays L.) in south-east Poland in 2004-2010]. Prog. Plant Prot./Post. Ochr. Roślin 51 (2): 593-598.

Fibiger M., Hacker H. 1991. Systematic list of the Noctuidae of Europe. Esperiance 2: 1-109.

Garnis J., Dąbrowski Z.T. 2008. Praktyczna ocena metod i technik stosowanych w monitoringu rolnicy zbożówki (Agrotis segetum L.). [Practical evaluation of some methods and techniques used in monitoring of common cutworm (Agrotis segetum L.)]. Prog. Plant Prot./Post. Ochr. Roślin 48 (3): 836-840.

Jakubowska M. 2009. Doskonalenie prognozowania krótkoterminowego chemicznej ochrony buraka cukrowego przed Agrotis segetum (Den. et Schiff.) i A. exclamationis (L.) (Lepidoptera: Noctuidae). Praca doktorska. Inst. Ochr. Roślin - PIB, Poznań, 176 ss.

Jakubowska M., Ławiński H. 2011. Przydatność wyników monitoringu rolnic (Agrotis sp.) na plantacjach buraka cukrowego dla potrzeb ochrony roślin. [Usefulness of cutworm monitoring results in sugar beet crops for the needs of plant protection]. Prog. Plant Prot./Post. Ochr. Roślin 51 (2): 570-576.

Jakubowska M., Lawiński H., Bandyk A. 2012. Monitoring rolnic (Noctuinae) jako element integrowanej ochrony buraka cukrowego. [The monitoring of cutworms as part of integrated pest of sugar beet]. Prog. Plant Prot./Post. Ochr. Roślin 52 (2): 229-234.

Jakubowska M., Walczak F. 2007. Wyznaczenie optymalnych terminów zwalczania rolnic w uprawach buraka cukrowego przy użyciu pułapek świetlnych i feromonowych. [Determination of optimum timing for chemical control of cutworms using light traps and pheromone traps]. Prog. Plant Prot./Post. Ochr. Roślin 47 (1): 238-243.

Jakubowska M., Walczak F. 2008. Wpływ temperatury i wilgotności powietrza na wybrane stadia rozwojowe rolnicy zbożówki (Agrotis segetum Schiff.) dla potrzeb prognozowania krótkoterminowego. [Influence of temperature and relative humidity on chosen development stages of (Agrotis segetum Schiff.) for requirements of short-term forecasting]. Prog. Plant Prot./Post. Ochr. Roślin 48 (3): 859-863.

Jakubowska M., Walczak F. 2009. Aktualne problemy ochrony buraków cukrowych przed rolnicą zbożówką i czopówką. [Current problems of sugar beet plants against Turnip moth and Heart and dart moth ]. Prog. Plant Prot./Post. Ochr. Roślin 49 (1): $116-121$.

Juszczak R., Leśny J., Olejnik J. 2008. Suma temperatur efektywnych jako element prognozy agrometeorologicznej Wielkopolskiego Internetowego Serwisu Informacji Agrometeorologicznej. Acta Agrophys. 12 (3): 409-426.

Lipa J.J. 1977. Masowy pojaw rolnic (Agrotinae) w Europie w latach 1975-1976 oraz badania nad ich patogenami w Polsce. Materiały 17. Sesji Nauk. Inst. Ochr. Roślin: 305-319.

Małachowska D. 1987. Metody sygnalizacji terminu zwalczania rolnicy zbożówki w Polsce. Gazeta Cukrownicza 2: 41-42.

Matyjaszczyk E., Tratwal A., Walczak F. 2010. Wybrane zagadnienia ochrony roślin w rolnictwie ekologicznym i integrowanej ochronie roślin. Inst. Ochr. Roślin - PIB, Poznań, 103 ss.

McMaster G.S., Wilhelm W.W. 1997. Growing degree-days: one equation, two interpretations. Agric. Forest Meteorol. 87: $291-300$.

Nowacki J. 1996. Klucze do oznaczania owadów Polski. cz. 27. Motyle (Lepidoptera). Pochodzenie: Piętnówki: Hadeninae. Turpress, Toruń, 88 ss.

Pruess K.P. 1983. Day-degree methods for pest management. En06ron. Entomol. 12: 613-619.

Tribel S.O., Fedorenko W.P., Lapa O.M. 2004. Sowki. Najposzireni v Ukraini 06dy. Kii, Kolobig, 77 pp.

Walczak F. 1999. Znaczenie monitoringu agrofagów roślin uprawnych dla ochrony roślin. [The importance of monitoring pests of crops for plant protection]. Prog. Plant Prot./Post. Ochr. Roślin 39 (1): 284-288.

Walczak F. 2003. Wykorzystanie metody regresji wielokrotnej przy wyznaczeniu optymalnego terminu chemicznej ochrony zbóż przed skrzypionkami (Oulema spp.) w Wielkopolsce. Rozpr. Nauk. Inst. Ochr. Roślin 12, 123 ss.

Walczak F., Jakubowska M. 2001. Wzrost szkodliwości rolnic (Agrotinae) w Polsce. [The increase in harmfulness of cutworms (Agrotinae) in Poland]. Prog. Plant Prot./Post. Ochr. Roślin 41 (2): 386-390.

Walczak F., Tratwal A., Krasiński T. 2010. Kierunki rozwoju prognozowania i sygnalizacji agrofagów w ochronie roślin rolniczych. [Directions of the development of pest forecasting and warning systems in plant protection]. Prog. Plant Prot./Post. Ochr. Roślin 50 (1): 81-86.

Zacha J. 1966. Prognoza a signalizace u ochrane rastnin. Stani, Praha, 10 pp. 